\title{
RESPONSE OF WILLIAMS BANANA PLANTS TO SOME $N, P, K$, AND BIO-FERTILIZERS FERTIGATION IN SANDY SOIL
}

\author{
HAMED AMANY M., SAMIA S. HOSNY AND EL-AGAMY
}

Tropical fruits Res. Dep. Hort. Res. Inst. ARC, Egypt

(Manuscript received 5 October 2011)

\begin{abstract}
This investigation was carried out during 2008/2009 and 2009/2010 seasons on the first and second ratoons of Williams banana grown in sandy soil to study the effect of three NPK rates $\left(600,100,800 \& 400,75,600 \& 300,50,400 \mathrm{~N}, \mathrm{P}_{2} \mathrm{O}_{5}, \mathrm{~K}_{2} \mathrm{O}\right.$ actual $\mathrm{g} /$ plant/year). Two types of biofertilizers microbien"N- fixation bacteria contained Azotobacter + phosphorus dissolving bacteria Bacillus brevis" and Potaplus"Potassuim dissolving bacteria Bacillus circulans" were divided to four different rate levels of biofertilizers $(0,25,50$ and $75 \mathrm{ml} /$ plant) added into 5 equal doses as a liquid suspension during the first week of April to August. Results revealed that the highest NPK rates $\left(600,100,800 \mathrm{~N}, \mathrm{P}_{2} \mathrm{O}_{5}, \mathrm{~K}_{2} \mathrm{O}\right.$ actual $\mathrm{g} /$ plant respectively) recorded the greatest vegetative growth (pseudostem highest and circumference as well as assimilation area), bunch weight and yield compared to other rates of fertilization, also it decreased the period to bunch shooting and fruit harvesting. Add biofertilizer led to an improvement in both vegetative growth and productivity. The rate of increase in vegetative growth represented by the length of the pesudostem to $18.75 \%$ and the pesudostem circumference to $16.65 \%$ and the assimilation area of the plant $17.30 \%$ compared to NPK alone. This may be due to the increase in leaf $\mathrm{N}$ and $\mathrm{K}$ content. Plants received NPK at 400,75 and 600 in addition to $75 \mathrm{~cm} /$ plant/year microben biofertilizer gave similar growth and productivity those reseved the higher NPK dose $(600,100,800)$ It was also noted that the addition of enriched biofertilizer microben given the highest bunch weight and productivity than the addition of enriched biofertilizer potaplus during the seasonal study.
\end{abstract}

Key word: biofertilizer, banana, yield, mineral fertigation .

\section{INTRODUCTION}

Sandy soil represent the most desert area in Egypt, and they usually deficient in organic matter and plant nutrients. Banana is one of the most important and popular fruit crops in Egypt and for its high nutritive value It is well known that banana needs large amounts of fertilizers especially nitrogen and potassium . Among these nutrients nitrogen is considered the prime nutrient for growth of plants. Fertilization is an important and limiting factor for growth and productivity of banana plants because plants consumed large amounts of nutrients from the soil . Moreover, it drew nutrient elements from a very limited soil depth due to its shallow roots system ( Hosny, 2010) So, the major problems facing banana growers are the high 
costs of excessive manufactured fertilizers needs for banana plants. Besides, these chemical fertilizers are considered air, soil and water pollutant agents during their producing and utilization. The pollution of soil and water resulted from leached chemical fertilizers into the soil, which transferred through the plants to the human and causes serious diseases. Hammam (2003) mentioned that using $N$ via mineral source and mixture of both Azotobacter and phosphate solublizing bacteria was significantly favored in improving fruit quality of Williams and Cavendish bananas in terms of increasing the TSS and total sugar and decreasing the percentage of starch and total acidity as compared to $\mathrm{N}$ completely added via mineral source .

The objective of this study was to evaluate the response of using some types of biofertilizers and mineral fertigation at different rates in aim to lead to minimize the use of chemical fertilizers on banana orchards.

\section{Material and Methods}

This investigation was carried out during two the successive seasons of $2008 / 2009$ and 2009/2010 on the first and second ratoons of Williams banana plants grown in sandy soil a private orchard at El Khatataba region, Menofia Governorate under the drip irrigation system. The select plants were cultivated at $3 \times 3 \mathrm{~m}$ apart similar as far as possible, free from any symptoms of diseases. Experimental plants received the same horticulture practices expect for the purpose of the study. Our expect consisted of two biofertilizers types at four level and three dose of $N, P, K$ at four level .

Physical and chemical analysis of the soil: The soil samples were collected from different location in the plantation at $60 \mathrm{~cm}$, depth and analysis for physical and chemical characters was done and data are shown in Table (1).

Table 1. Some physical and chemical analysis of orchard soil during season of 2008

\begin{tabular}{|c|c|c|c|}
\hline \multirow{2}{*}{ Physical character } & \multirow{2}{*}{ value } & $\frac{\text { Chemical constituents }}{\text { Available macro-nutrients }}$ & \\
\cline { 3 - 4 } & & $\frac{(\%)}{\mathrm{N}}$ & \\
Clay \% & 5 & $\mathrm{P}$ & 0.90 \\
Silt \% & 5 & $\mathrm{~K}$ & 0.28 \\
Sand \% & 90 & $\frac{\text { Available micro-nutrients }}{2}$ & 0.36 \\
Texture & Sandy & $\frac{(\mathrm{ppm})}{\mathrm{Zn}}$ & \\
Ec mmhos/cm 1:2.5 & 1.5 & $\mathrm{Fe}$ & 0.28 \\
pH & 8.29 & $\mathrm{Mn}$ & 2.38 \\
Organic matter\% & 0.65 & & 0.58 \\
$\mathrm{CaCO}_{3} \%$ & 1.60 & & \\
\hline
\end{tabular}

To evaluate the response of Williams banana plants to bio and chemical fertilizers. Our experiment consisted of two biofertilizers types at four level $(0,25$, 50 , and $75 \mathrm{~cm} /$ plant) and three doses of N,P,K . Three NPK rates $(600,100,800 \&$ $400,75,600 \& 300,50,400 \mathrm{~N}, \mathrm{P}_{2} \mathrm{O}_{5}, \mathrm{~K}_{2} \mathrm{O}$ actual $\mathrm{g} /$ plant from respectively) in the forms 
(ammonium nitrate $33.5 \% \mathrm{~N}$, phosphoric acid $80 \%$ and potassium sulphate $48 \%$ $\mathrm{K}_{2} \mathrm{O}$ ) were assignees to main plots. Two types of biofertilizers microbien and Potaplus were divided to four different rat levels of biofertilizers $(0,25,50$ and $75 \mathrm{~cm} /$ plant) added into 5 doses equal as a liquid suspension during the first week of April to August, for each season. Microben is the commercial name of " $\mathrm{N}$ - fixation bacteria contained Azotobacter + phosphorus dissolving bacteria Bacillus brevis. The other biofertilizer Potalus contained only Potassuim dissolving bacteria Bacillus circulans. Both biofertilizers were divided. One $\mathrm{cm}$ of biofertilizer contained $10^{8}$ cells according to the General Organization for Agriculture Equalization Fund ( GOAEF )

The experimental design was split split plot design of three replicates, each replicate content ten plants. The three chemical were located in the main plots, two types of biofertilizers were arranged in sub-plot and the four levels of biofertilizers were randomly distributed in sub-sub-plot.

Growth characters : At bunch shooting stage, the following growth characteristics were recorded: pseudostem height, pseudostem circumference $(\mathrm{cm})$, number of green leaves per plant as well as assimilation area/plant $\left(\mathrm{m}^{2}\right)$ was determined using the equation. = leaf area $\times$ number of green leaves/plant ( Ibrahium 1993). Data of each plant were individually recorded

Flowering and maturation: The period from emergence to bunch shotting and period from bunch shooting to date of harvesting in days were caculated.

Yield characteristics: At time of harvest, bunch weight $/ \mathrm{kg}$ and yield / ton was determined.

Leaf chemical constituents : From each treatment, a $10 \mathrm{~cm}^{2}$ from the third leaf from the top of the plant in each individual plant at bunch shooting stage was taken.Total nitrogen was determined by Micro-Kjeldahle method as described by Jackson (1967), Phosphorus was determined according to the method of Chapman and pratt (1964) and K was determined by using the Atomic absorption Spectrometer ( Per Kin - Elemer, Model 3300)according to the methods described by Chapman and Pratt (1964).

Statistical analysis: The experimental data were tabulated and statistically analyzed according to Snedecor and Cochran (1980) and the differences between mean various treatments were compared by using new L.S.D. at $5 \%$ level.

\section{RESULTS AND DISCUSSION}

Vegetative growth: concerning the effect of $\mathrm{N}, \mathrm{P}, \mathrm{K}$ in vegetative growth, data in Tables $(2,3,4$ and 5$)$ indicated that, the higher $N, P, K$ fertigation rate $(600,100,800)$ exhibited the higher value of pseudostem height and circumference, number of leaves/plant as well as assimilation area comparing with those of the two other tested 
rates. Adding, biofertilizers to the $\mathrm{N}, \mathrm{P}, \mathrm{K}$ applications resulted in significant increase in vegetative growth measurements and these increase were associated with the rates of biofertilizers. Differences were at significant level in most cases. Treatment in which the plant received $N, P, k$ at $(600,100,800 \mathrm{~g} /$ plant $)$ plus $75 \mathrm{~cm}$ microben exhibited the higher vigor values. This was true in the two experimental seasons.

These results are in agreement with those reported by El Moniem and Radwan, 2003 and Saad and Saad,2007 on banana plant . In addition, (Hosny,2010) reported that different biological systems are greatly affected by soil treatment, efficiency and number of organisms portability between organisms and with specific host plant, quantity and availability of nutrient elements, soil $\mathrm{pH}$, organic matter and salinity.

Flowering and maturation: Data in Tables (6 and 7) showed that increasing NPK level showed significant decreases in the time to flowering and harvesting. It is also clearly that, adding microben to NPK fertilizer significantly reduced the period to flowering comparing with the other tested biofertilizer. The reduction in time to flowering was associated with the increase in biofertilizer rates. Moreover, Azotobacter and Azospirillum strains produce a adequate amounts of IAA and cytokinin which increase the surface area per unit root length and encourage root hair branching with an eventual. Increasing in absorption of nutrients from the soil and thus promote plant growth (Martin et. al., 1989 ). Again, these results are in agreement with those reported by El Saammaa, 2001, Abd El-Aziz, 2002, Abd- El Moniem and Radwan, 2003, Gogo et. al., 2004 and Mai et. al., 2005 on banana plants

\section{Bunch weight $(\mathbf{k g})$ and yield (ton/fed)}

Data in Tables (8 and 9) indicated that the higher $\mathrm{N}, \mathrm{P}, \mathrm{K}$ fertigation rate of NPK $\mathrm{N}, \mathrm{P}_{2} \mathrm{O}_{5}, \mathrm{~K}_{2} \mathrm{O}(600,100,800 \mathrm{~g} /$ plant)significantly enhanced bunch weight and yield. Concerning, the effect of varying biofertilizers source data showed a significant differences on bunch weight and yield. Adding biofertilization lead to bunch weight and yield improvement, and the rate of increase were $24.8 \%$ \& $24.55 \%$ and $26.3 \%$ $\& 25.6 \%$ in both seasons, respectively. Consequently, the most increasing effect of bunch weight and yield in this respect was to fertilizing with $600,100,800 \mathrm{~N}, \mathrm{P}_{2} \mathrm{O}_{5}, \mathrm{~K}_{2} \mathrm{O}$ $\mathrm{g} /$ plant and $75 \mathrm{~cm}$ microben biofertilizer which recorded the highest value ( 31.9 \&31.9 and $31.9 \& 31.09$ ) in both seasons respectively. Moreover, the effect of the biofertilizer increased cell divisions and enlargement and consequently increased vegetative growth which reflected on increasing the yield and yield components as finally result from the physiological processes (El-Kafrawy, 2005). Again, these results are in agreements with those reported by Abd El Naby (2000), Awad and ElShenawi(2005) and Merwad (2007) on banana plants. 


\section{NPK content in leaves}

Data in Table (10) clearly indicated an increase in nitrogen content in leaves from plants under higher NPK fertigation rate $600+100+800 \mathrm{~g} /$ plant. Plants which treated with microben biofertilizer gave the high content of $\mathrm{N}$ in leaves if compared with leaves of plants fertilized by potassuim dissolving bacteria (potalup) biofertilizer and non -biofertilizers. Regarding, interactions between NPK doses, biofertilizers and different rate of biofertlizers were statistically significant and gradually increased with increasing the rate of NPK and microbin biofertilizer. Moreover, Hammam, (2003) reported that $A$. brcailenseis known to be able to produce plant hormones like auxins and other plant growth substances in the rhizosphere of inoculated plants.. Again, these results are in agreement with those reported by Abd El Naby, 2000 and Saad et. al., 2007 on banana plants.

Data in Table (11) clearly indicated an increase in potassium content in leaves from plants under higher NPK fertigation rate $600+100+800 \mathrm{~g} /$ plant. Plants treated with potalpus biofertilizer gave the high content of $\mathrm{P}$ in leaves if compared with leaves of plants fertilized by microben biofertilizer and non -biofertilizers .Regarding, the effect of different rate levels of biofertilizer on nitrogen content in leaves data in same table clearly showed that, application with the highest rate $(75 \mathrm{~cm} /$ plant $)$ potaplus biofertilizer recorded the highest value 4.3 and $4.4 \%$ in both seasons respectively. As for interactions between NPK doses, biofertilizers and different rate of biofertlizers were statistically significant and gradually increased with increasing the rate of NPK and potalpus biofertilizer. These data agreed with the results reported by Hosny (2010) who found that the better performance of feldspar-compost plus silicate dissolving bacteria could be attributed to better maintenance of soil nutrient status in the root zone, which in turn helped the plants to utilize nutrients more efficiently, release of potassium took place frequently, and thus favorably affects growth of the crop. Recently, Massoud et. al. (2009) reported that AM-fungi inoculation combined to B. circulans is highly beneficial to the growth of plants.

Data in Table (12) indicated that, no significant differences in P content in banana leaves which fertilized with both NPK and biofertilizer at different rates in both seasons. As for interaction study between NPK rates, biofertilizers and different doses of biofertlizers were statistically insignificant pointing to their independence in this respect this came true in both seasons. In this concern, El-Kafrawy, (2005) reported that, the effect of inoculation with Azospirillum spp may be due to different mechanisms, $\mathrm{N}$ - fixation, production of plant growth substances and enhancement uptake of nitrite, phosphate and potassium . Again, these results are harmony with finding of Abd El Naby, 2000, Abd El Aziz (2002), Saad et. al., 2007 on banana plants. 
Table 2. Effect of NPK fertigation and Bio fertilizers on pseudostem height and circumference of Williams banana plants grown in sandy soil (2008/2009 season).

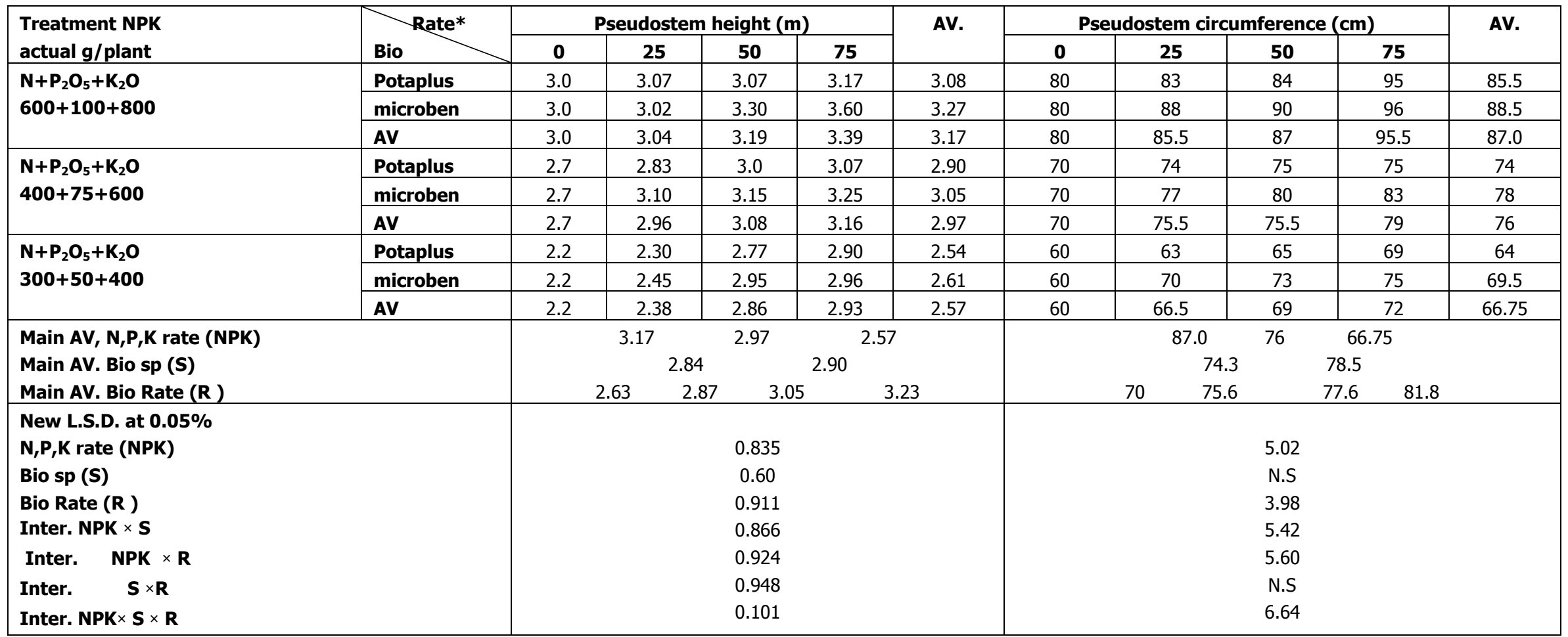

$* \mathrm{~cm} /$ plant 
Table 3. Effect of NPK fertigation and Bio fertilizers on pseudostem height and circumference of Williams banana plants grown in sandy soil (2009/2010 season).

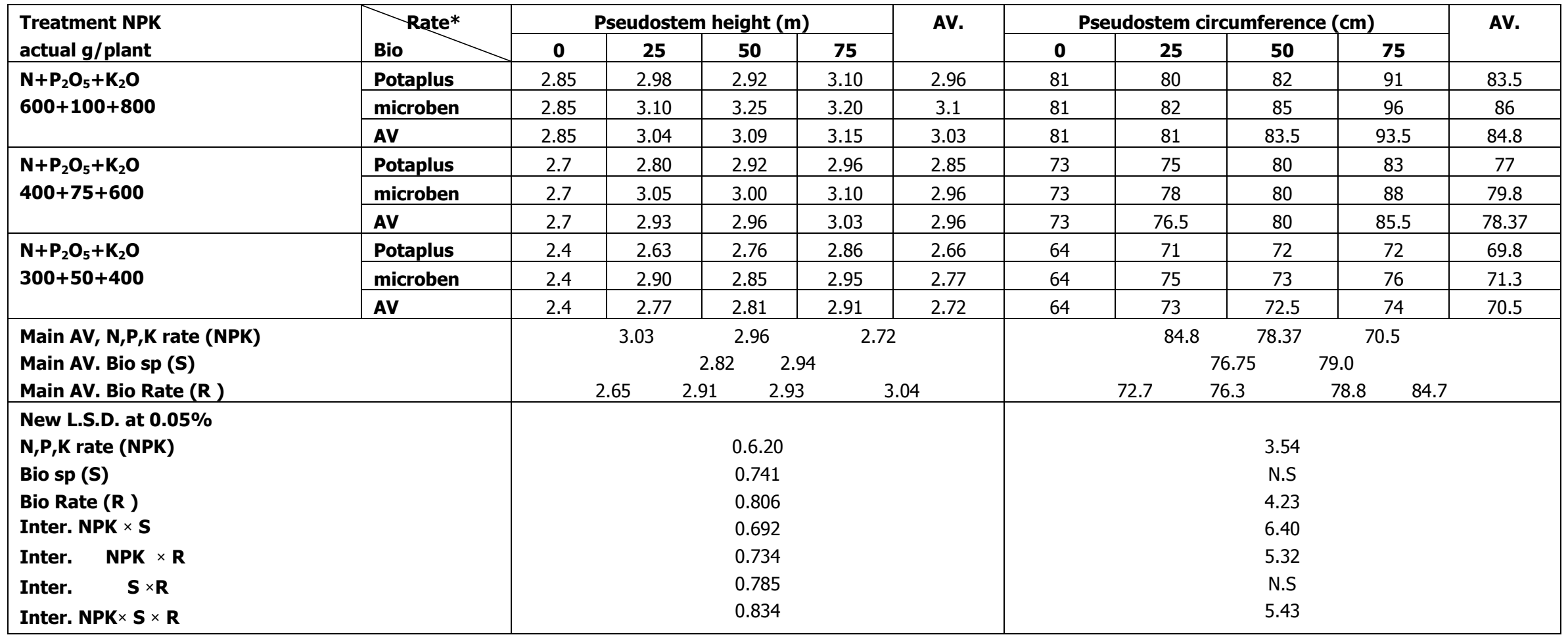

$* \mathrm{~cm} /$ plant 
Table 4. Effect of NPK fertigation and Bio fertilizers on number of leaves/plant and assimilation area of Williams banana plants grown in sandy soil (2008/2009 season).

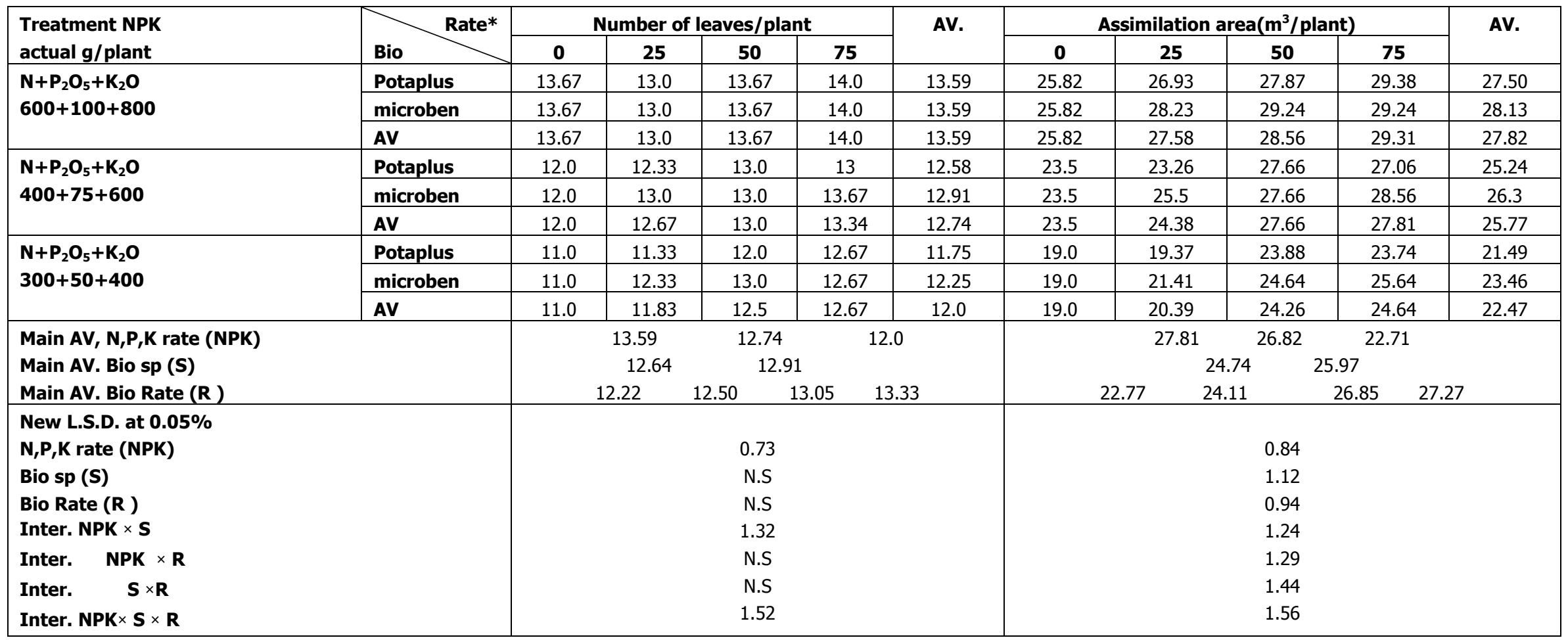

$*_{\mathrm{cm}}$ plant 
Table 5. Effect of NPK fertigation and Bio fertilizers on number of leaves/plant and assimilation area of Williams banana plants grown in sandy soil (2009/2010 season).

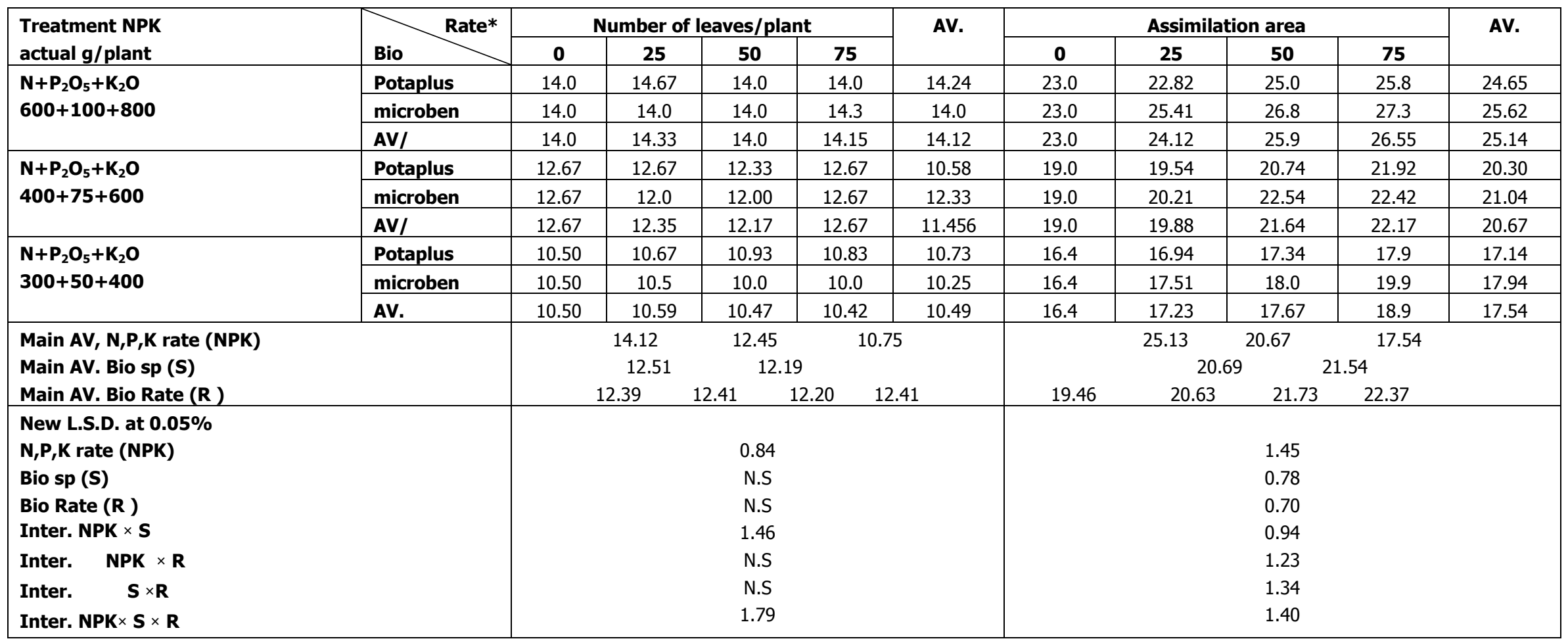

* cm/plant 
Table 6. Effect of NPK fertigation and Bio fertilizers on time to flowering and time to harvesting of Williams banana plants grown in sandy soi (2008/2009 season).

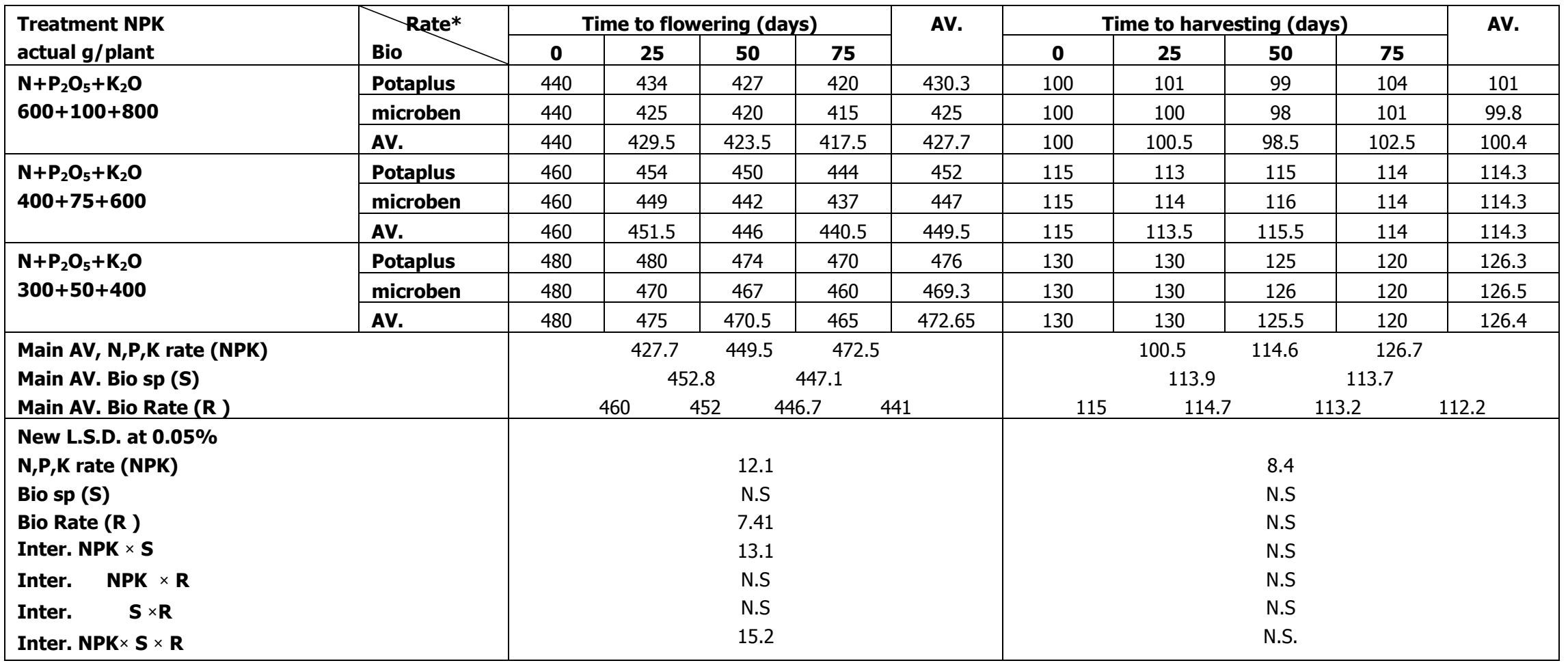

$* \mathrm{~cm} /$ plant 
Table 7. Effect of NPK fertigation and Bio fertilizers on time to flowering and time to harvesting of Williams banana plants grown in sandy soil (2009/2010 season).

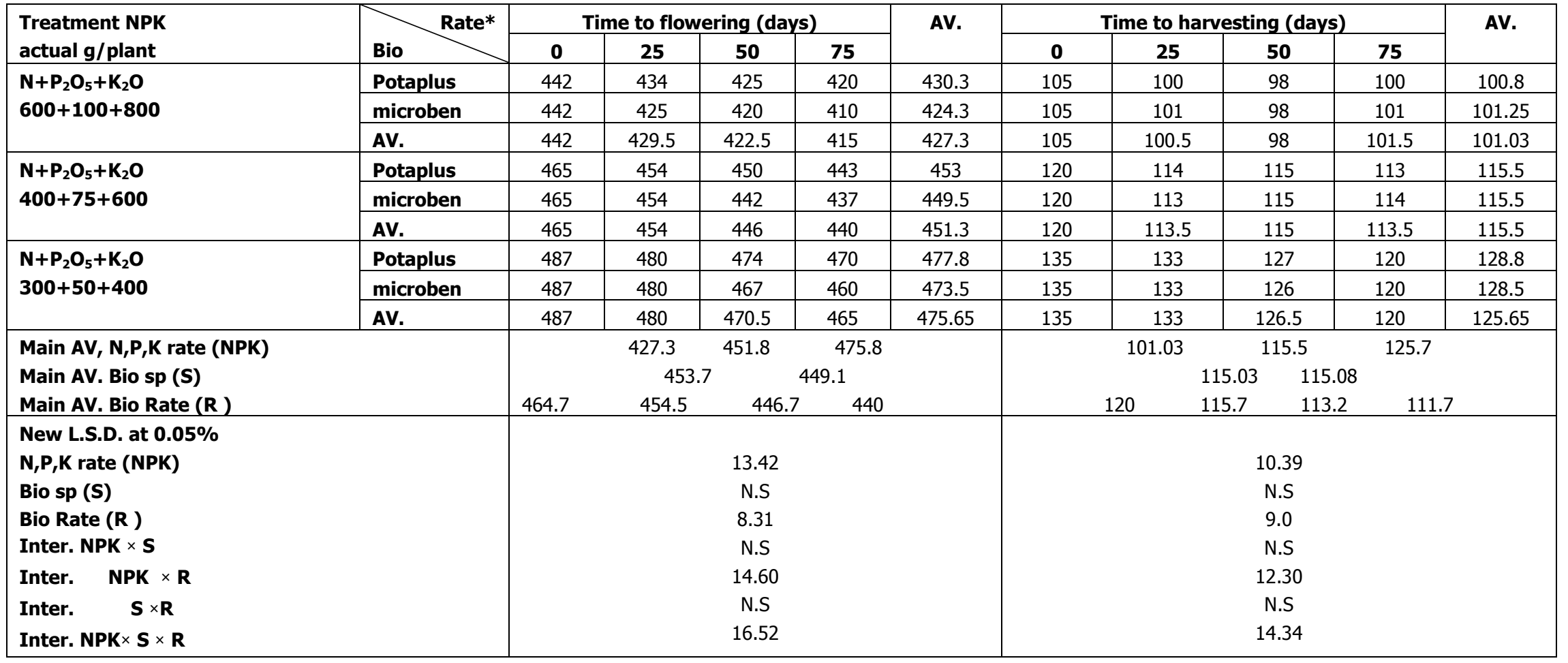

$* \mathrm{~cm} /$ plant 
Table 8. Effect of NPK fertigation and Bio fertilizers on bunch weight and yield of Williams banana plants grown in sandy soil (2008/2009 season).

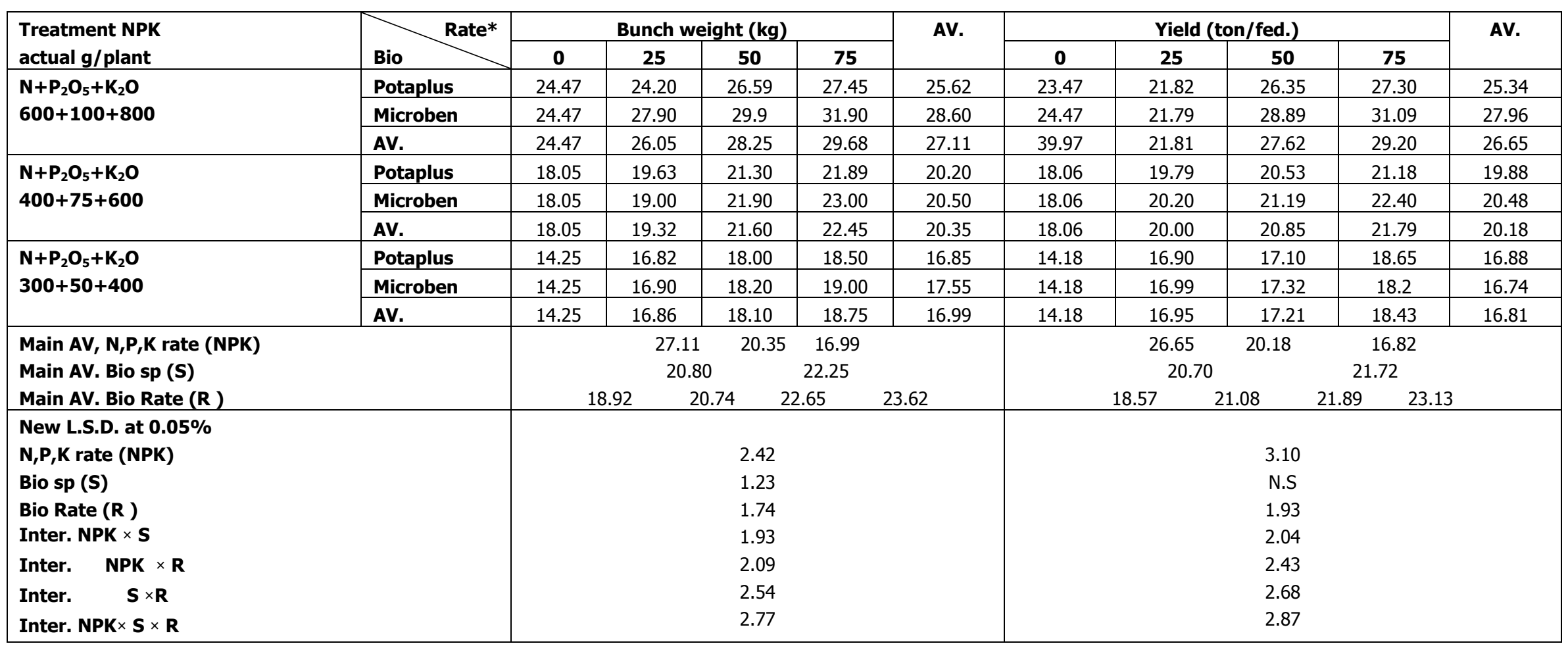

* cm/plant 
Table 9. Effect of NPK fertigation and Bio fertilizers on bunch weight and yield of Williams banana plants grown in sandy soil (2009/2010 season).

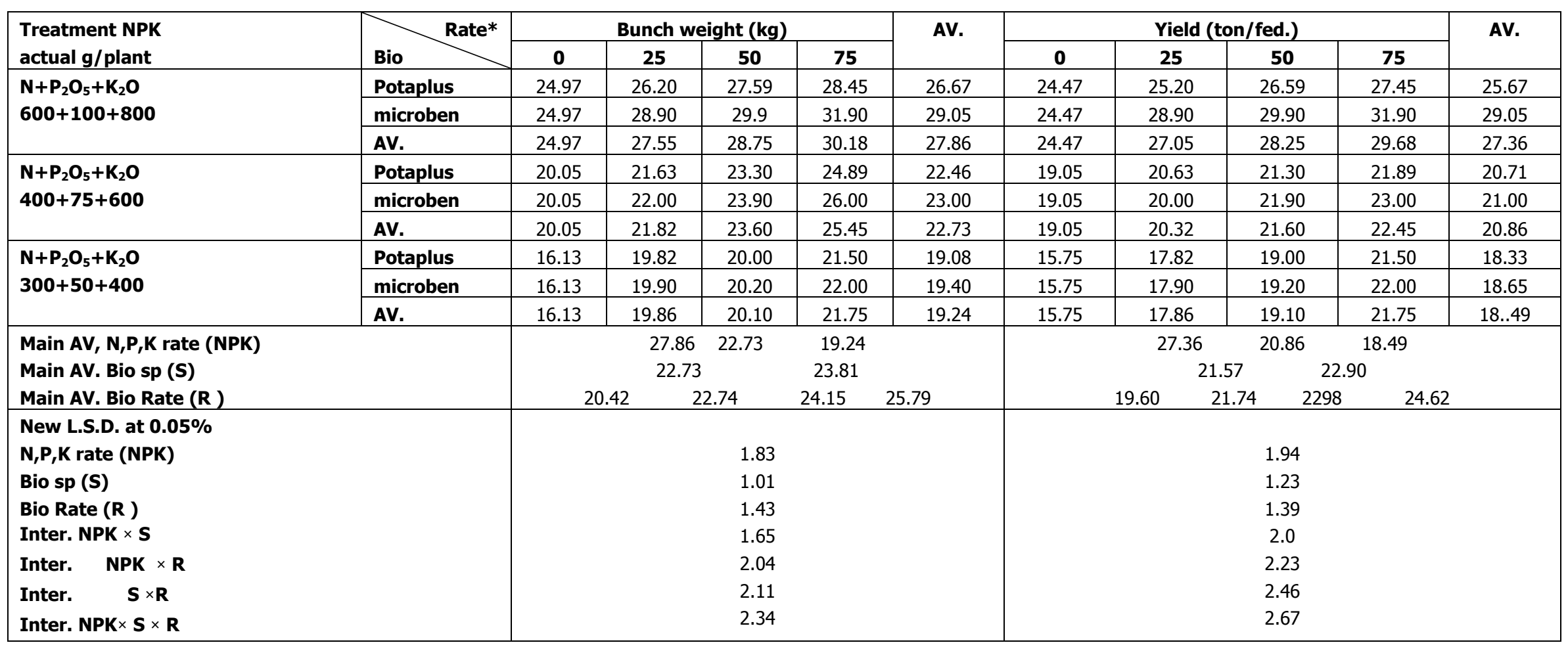

* cm/plant 
Table 10. Effect of NPK fertigation and Bio fertilizers on nitrogen content in leaves of Williams banana plants grown in sandy soil (2008/2009 and 2009/2010 seasons).

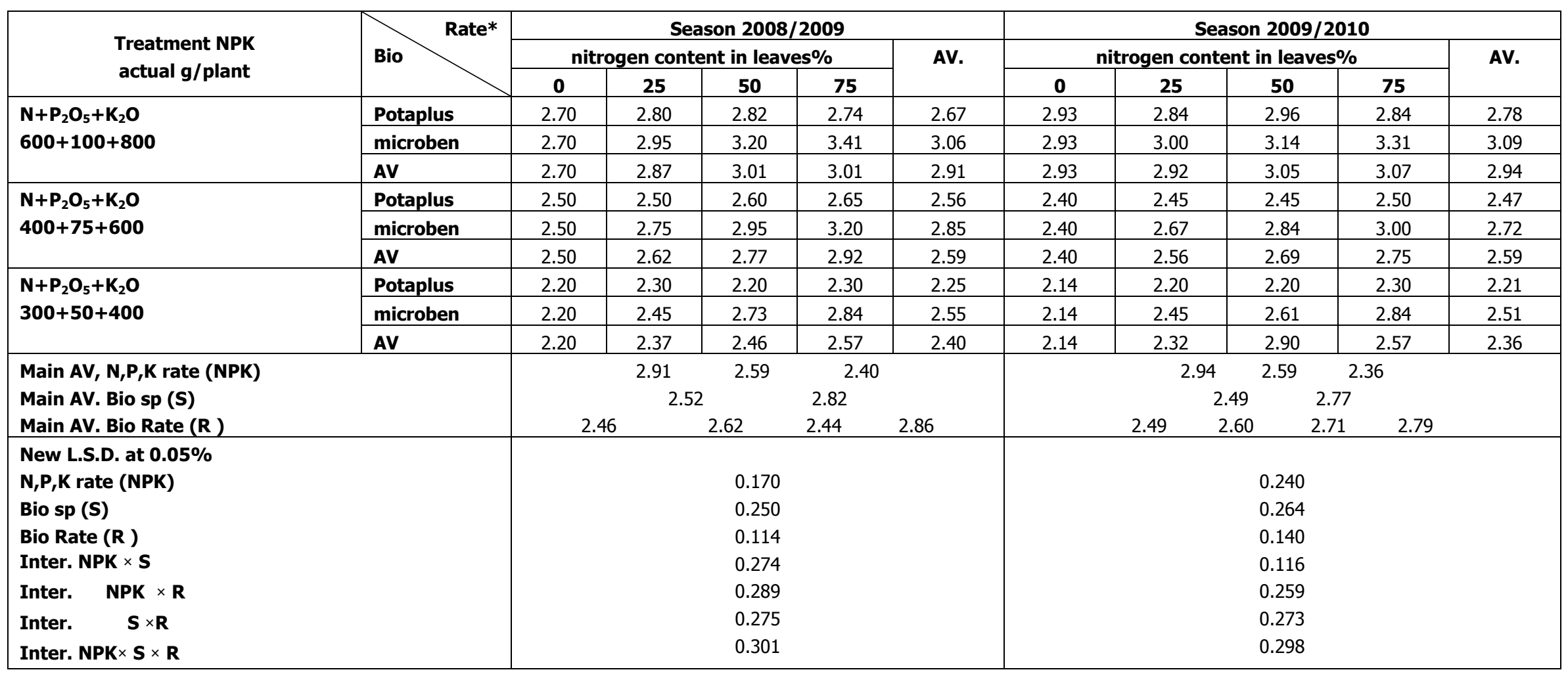

$* \mathrm{~cm} /$ plant 
Table 11. Effect of NPK fertigation and Bio fertilizers on potassium content in leaves of Williams banana plants grown in sandysoil (2008/2009 and 2009/2010 seasons).

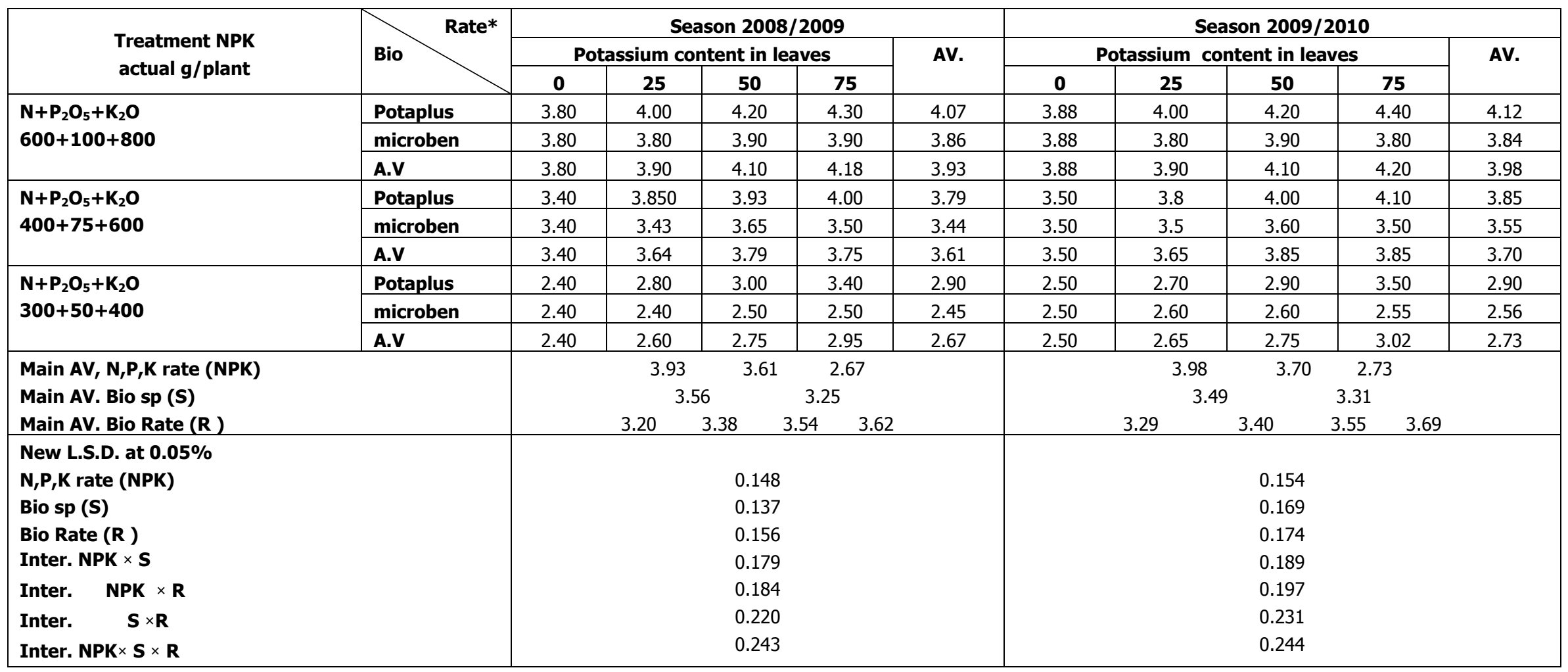

$* \mathrm{~cm} /$ plant 
Table 12. Effect of NPK fertigation and Bio fertilizers on phosphorus content in leaves of Williams banana plants grown in sandy soil (2008/2009 and 2009/2010 seasons).

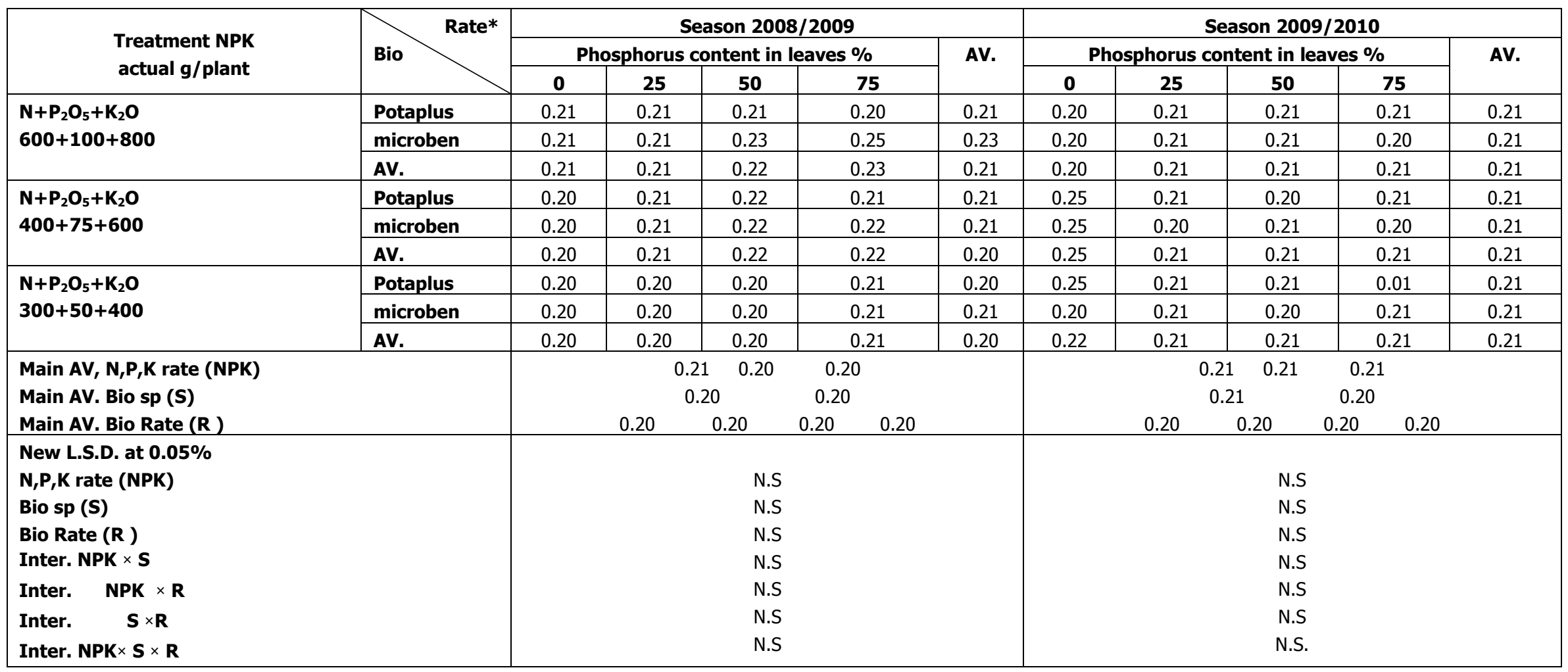

$*_{\mathrm{cm} / \text { plant }}$ 


\section{REFERENCES}

1. Abd El-Aziz, A.B.K. 2002. Physiological studies on biofertilization of banana plants cv. Williams. Ph.D. Thesis, Fac. Agric. Minia University .127p.

2. Abd- El-Moniem, E.A.A. and S.M.A. Radwan. 2003. Response of Williams banana plants to biofertilization in relation to growth, productivity and fruit quality. Arab Univ. J. Agric. Sci., Ain Shams Univ., Cairo, 111(2):751-763.

3. Abd El-Naby, S K. M. 2000. Effect of banana compost as organic manure on growth , nutrients status, yield and fruit quality of Maghrabi banana. Assuit J. Agric. Sci., 3:101-114.

4. Awad, A.M. and M.R. El - Shienawi. 2005. Intergrated production technique for banana "Williams" using organic and mineral NK fertilization in calareous soils. Assiut J. of Agric. Sci., 36(4) :21-43.

5. Chapman, H.D. and P.F. Pratt. 1964. Methods of analysis for soils. Plant and Water. Div. Agric. Sci. Univ., California U.S.A. 150 p.

6. El- Kafrawy, A. A. M. 2005. Physiological studies on banana plant. Ph.D. Thesis. Fac.Agric., Moshtohor Zagazig Univ. Egypt, 210p.

7. El- Shammaa, M. S. 2001. Effect of biofertilizers on growth and yield of banana plants (cv. Williams ). Assuit J. Agric. Sci., 32(1): 157-166.

8. Gogoi, D., U. Kotoky and S. Hazarika. 2004. Effect of biofertilizers on productivity and soil charcteristics in banana. Indian J. Hort. 61(4):354-356. (C.F. CAB. Abst., 0030-29415)

9. Hammam, M. S. 2003. Effect of biofertilization on growth and fruiting of Cavendish and Williams bananas . Egypt. J. Hort., 30(1-2): 67-81.

10. Hosny, S.S.A.. 2010. Physiological studies on nutrition of banana plants. Ph.D. Thesis, Fac. Agric Cairo University.

11. Ibrahim, El.S.G. 1993. Studies on irrigation of banana. Ph. D. Thesis, Fac. Agri. Zagazig Univ.Egyp.

12. Jackson, M. L. 1967. Soil chemical analysis. Prentice- Hall , Inc.. Englewood Cliff, N. J. Libarary Congress, U.S.A. 120 p.

13. Mai, M. A. B., Z. H., Shamsuddin, W. Zakaria and M. Mahmood. 2005. High yielding and quality banana production through plant growth Promoting rhizobacterial (PGPR) inoculation. Fruits Paris, 60(3): 179-185. 
14. Massoud, O.N., Morsy, M. Ebtsam and El- Batanony, H. Nadia. 2009. Field response of snap bean (Phaseolus vulgaris L.) to N2-fixers Bacillus circulans and Arbuscular mycorrhizal fungi inoculation through accelerating rock phosphate and feldspar weathering. Australian Journal of Basic and Applied Sciences. 3: 844852.

15. Merwad, M. M. A. 2007. Effect of some organic and biofertilization treatments on growth and productivity of Grand Nain banana plants . M.Sc. Thesis. Fac.Agric., Zagazig Univ. Egypt, 137p.

16. Saad, I. R. and M. M. Saad. 2007. Effect of different organic nitrogen sources on growth, yield and fruit quality of Williams banana .J. Adv. Agric. Res., 12(1):149164.

17. Snedecor, G. W. and W. G. Cochran. 1980. Statistical methods, $6^{\text {th }}$ ed Iowa State Univ. Press., Ames, U.S.A., 150 p. 
استجابة نباتات الموز الوليامز لبعض الأسمدة المعدنية والمخصبات الحيوية

\section{في الأراضي الرملية}

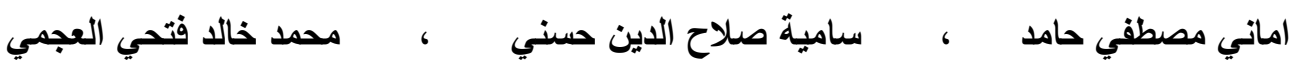

$$
\text { قسم بحوث الفاكهة الاستوائية - معهد بحوث البساتين - مركز البحوث الزراعية - مصر }
$$

أجري هذا البحث علي الخلفة الأولي والثانية لنباتات الموز صنف ويليامز خلال الموسمين المتتالين 2009/2008 و 2010/2009 النامية في ارض رملية لدراسة الاحتياجات السمادية من النتروجين والفوسفور والبوتاسيوم في صورة نتروجين وأكسيد بوتاسيوم وخامس أكسيد الفوسفور بمعدلات مختلفة

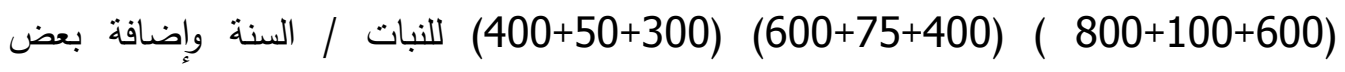
المخصبات الحيوية منل ميكروبين ( بكتريا مثبية للنتروجين +بكتريا مذيبة للفوسفور) و بوتابلس (بكتريا مذيبة للبوتاسيوم) بمعدلات صفر ، 25 ، 50، 75 سم/نبات /سنة أضيفت علي خمس دفعات منساوية من اول أبريل الي أغسطس وذللك بهدف تقليل استخدام الأسمدة المعدنية وكانت أهم النتائج المتحصل عليها:1- أعطت معاملة المعدل الأعلي للتسميد المعدني ( 800+100+600 ) أفضل نتائج لنمو الخضري من طول ومحيط الساق الكاذبة والمساحة الفعالة للنبات ووزن السباطة والمحصول

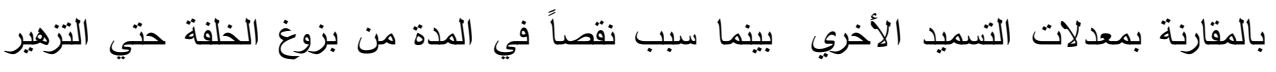
والجمع.

2- اضافة المخصبات الحيوية ادت الي تحسين في خصائص صفات النمو الخضري والمحصول

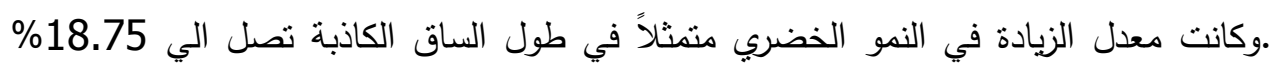

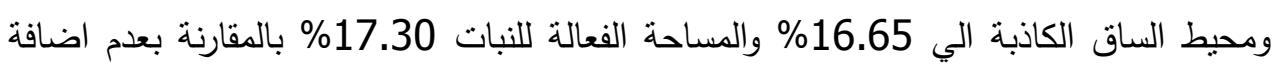
الأسمدة الحيوية وهذا راجع الي زيادة محتوي الآوراق من عنصري النتروجين والبوتاسيوم نتيجة اضافة المخصبات الحيوية وتأثيرهم علي المحصول. برنامج التسميد المقترح تحت ظروف الأرض الرملية التي أجريت بها هذا البحث لصنف الموز يوصي بالتسميد المعدني Williams ميكروبين حيث اعطت اعلي وزن للسوباطة والمحصول خلال موسمي الدراسة. 